\title{
Prevalence and Molecular Characterization of Salmonella Isolated from Broiler Farms at the Tolima Region-Colombia
}

\author{
Roy Rodríguez-Hernández ${ }^{1}\left(\mathbb{D}\right.$, Johan F. Bernal ${ }^{2}{ }^{\mathbb{D}}$, Jimmy F. Cifuentes ${ }^{3}$, Luz Clemencia Fandiño ${ }^{1}$, \\ María P. Herrera-Sánchez ${ }^{1,3}\left[\mathbb{D}\right.$, Iang Rondón-Barragán $1,3, * \mathbb{C}$ and Noel Verjan Garcia ${ }^{1,3}$ \\ 1 Poultry Research Group, Faculty of Veterinary Medicine, University of Tolima, Altos the Santa Helena, \\ A.A 546, Ibagué 730006299, Colombia; royrodriguezh@ut.edu.co (R.R.-H.); Ifandino@ut.edu.co (L.C.F.); \\ mpherreras@ut.edu.co (M.P.H.-S.); nverjang@ut.edu.co (N.V.G.) \\ 2 Investigación y Vigilancia Integrada de la Resistencia Antimicrobiana, Agrosavia, Km 14 Vía \\ Mosquera-Bogotá CI Tibaitatá, Mosquera 250047, Colombia; jfbernal@agrosavia.co \\ 3 Immunobiology and Pathogenesis Research Group, Faculty of Veterinary Medicine, University of Tolima, \\ Altos the Santa Helena, A.A 546, Ibagué 730006299, Colombia; jimmytoci@gmail.com \\ * Correspondence: isrondon@ut.edu.co; Tel.: +57-300-498-1037
}

check for updates

Citation: Rodríguez-Hernández, R.; Bernal, J.F.; Cifuentes, J.F.; Fandiño,

L.C.; Herrera-Sánchez, M.P.;

Rondón-Barragán, I.; Verjan Garcia,

N. Prevalence and Molecular

Characterization of Salmonella Isolated from Broiler Farms at the Tolima Region-Colombia. Animals 2021, 11, 970. https://doi.org/ 10.3390/ani11040970

Academic Editor: Morgan B. Farnell

Received: 20 February 2021

Accepted: 9 March 2021

Published: 31 March 2021

Publisher's Note: MDPI stays neutral with regard to jurisdictional claims in published maps and institutional affiliations.

Copyright: (c) 2021 by the authors. Licensee MDPI, Basel, Switzerland. This article is an open access article distributed under the terms and conditions of the Creative Commons Attribution (CC BY) license (https:// creativecommons.org/licenses/by/ $4.0 /)$.
Simple Summary: Salmonella spp. is a major foodborne pathogen with a worldwide distribution that is responsible for salmonellosis in animals and humans. Salmonella contamination of poultry and derivative products occurs at different levels. The aim of this study was to estimate the prevalence of Salmonella in broilers farms and to conduct a phenotypic and molecular characterization of Salmonella isolates. The prevalence at the broiler farm level was $26.67 \%$, and all isolates were found to belong to the serovar Salmonella Paratyphi B. These results suggest a common source of Salmonella contamination between broiler farms, presumably via feed, parent flocks or hatchery machines. Salmonella Paratyphi B is present in different segments of the poultry chain in the Tolima region. Additional studies are needed to identify the main source of Salmonella in broilers, chicken carcasses, and eggs commercialized in the Tolima region.

Abstract: Salmonella is an important animal and human pathogen responsible for Salmonellosis, and it is frequently associated with the consumption of contaminated poultry products. The aim of this study was to estimate the prevalence of Salmonella in the poultry farms and to determine the genetic relationship. A total of 135 samples collected from fifteen broiler farms, including cloacal, feed, water, environmental and farm operator faeces samples were subjected to microbiological isolation. Molecular confirmation of Salmonella isolates was carried out by amplification of the invA gene, discrimination of d-tartrate-fermenting Salmonella isolates using multiplex PCR, and subsequently analysed by pulsed-field gel electrophoresis (PFGE). A survey questionnaire was conducted to identify potential risk factors for Salmonella presence in broiler farms. The prevalence of Salmonella at the farm level was $26.67 \%$, and Salmonella isolates were serotyped as S. Paratyphi B and all isolates were d-tartrate-fermenting $(\mathrm{dT}+)$. PFGE showed three highly similar clusters and one significantly different Salmonella isolate. S. Paratyphi B continued to be present in different links of the poultry chain in the Tolima region, and identification of its main source is necessary to control its dissemination.

Keywords: broilers; Salmonella; PFGE; prevalence; risk factors

\section{Introduction}

Globally, foodborne diseases are common illnesses caused by consumption of contaminated food; nearly 550 million people become ill from diarrheal disease, including 220 million children [1]. Salmonella spp. is a major foodborne pathogen with worldwide distribution that is responsible for salmonellosis in animals and humans [2-4]. Consumption of Salmonella-contaminated food may result in human non-typhoidal salmonellosis, 
which is one of the leading causes of gastroenteritis in the world [5]. Human salmonellosis occurs mainly by ingestion of contaminated food from animal origin, frequently from poultry products such as eggs and raw chicken $[6,7]$. In the United States, Salmonella spp. is responsible for about 1.35 million infections, and 420 deaths every year, and in the European Union nearly 91,000 cases occur each year $[3,8]$. In Colombia, the National Health Institute (INS) in Bogota, reported 13,769 cases of foodborne diseases during 2018, of which 911 strains of Salmonella were isolated and a similar number of Salmonella spp. were obtained in 2015 and 2016. Of note, S. Typhimurium and S. Enteritidis continue being the most prevalent serovars [9].

Salmonella contamination of poultry and derived products may occur at different levels. Several sources of Salmonella infection/contamination have been described in primary production, including contaminated feed and water, asymptomatic birds, wild birds, rats and flies [10-12]. Second, in the post-production phase, during processing of chickens in abattoirs, contact with contaminated surfaces of cages during transport and market exhibition, among others, have been described as potential sources of Salmonella contamination $[12,13]$. Finally, direct contamination of poultry products by food handlers during cooking at formal and informal food vendors and homes cannot be excluded.

In Colombia, studies conducted in the poultry production chain in 2012 reported a $41.4 \%$ prevalence of Salmonella in broiler farms from Santander and Cundinamarca regions [14]. Later, the prevalence of Salmonella in broiler farms sampled in Santander in 2015 was only $2.8 \%$ [15]. In the Tolima, a prevalence of 33.33\% Salmonella was reported in laying hen farms [12], likewise, a prevalence of $17.41 \%$ and $2.93 \%$ were reported in raw chicken meat and commercialized eggs in the same region, respectively [12,13]. In addition, our research group confirmed the presence of Salmonella spp. in about $10 \%$ $(n=110)$ of clinical cases of human gastroenteritis admitted in the period of August to December 2015 from local health care centres in Ibagué city [7]. Likewise, our studies established a clonal relationship between $S$. Enteritidis from poultry and human isolates, revealing the importance of Salmonella in public health and the need for robust studies with deep coverage that should address additional risks of contamination, the distribution and association with human clinical events. To increase the understanding of Salmonella epidemiology in the Tolima region, for this purpose the aim of this study was to estimate the prevalence of Salmonella in poultry farms and to determine the genetic relationship.

\section{Materials and Methods}

\subsection{Study Population}

The Tolima district is located between the central and eastern mountains of the Colombian Andes, and it has 42 municipalities with approximately 4 million broilers at 90 farms. The Tolima region, together with Cundinamarca, Huila and Boyacá, represent the largest broiler producer regions in Colombia.

\subsection{Study Design}

A cross-sectional study was designed to estimate the prevalence of Salmonella spp. in broiler farms. The sampled farms were selected by convenience. We chose a nonprobabilistic method because the study depended on the farm owner's decision to participate in the study. Thus, only 15 commercial broiler farms from three different companies in the Tolima region allowed us to conduct confidential sampling. Two poultry houses for each farm were sampled for Salmonella detection using different samples types. All poultry houses sampled were surrounded by a natural environment, and the bird density ranged from 7 to 9 hens $/ \mathrm{m}^{2}$. The facilities structures were made in bamboo or metal and the floor was soil or concrete. All farms were found to store the feed bags inside the poultry house. Human faecal samples were voluntarily provided by poultry operators involved in the study through informed consent, based on Resolution 8430-1993 from the Colombian Healthcare department. This study was approved by a Central Research office committee at the University of Tolima, and the approval number was 130214. 


\subsection{Sample Collection}

A total of 135 samples were collected from fifteen broiler farms between the period 2015-2016. The samples included cloacal swab pools $(n=75)$, feed samples $(n=15)$ water samples $(n=15)$, boots swab samples $(n=15)$ and faecal samples $(n=15)$ provided by farm operators. Cloacal swabs were obtained from chickens selected randomly in each house, making 5 pools of 10 birds per flock ( 50 bird/flock) and a total of 750 birds were sampled. The age of the sampled chickens ranged between 12 to 42 days-old. The feed samples were taken from newly opened feed bags at the moment of the sampling and consisted of $250 \mathrm{~g}$ of feed collected in sterile bags (Nasco ${ }^{\circledR}$, Fort Atkinson, WI, USA). The water samples consisted of $250 \mathrm{~mL}$ collected in Whirl-Pak ${ }^{\mathrm{TM}}$ Standard Sample Bags $\left(\mathrm{Nasco}^{\circledR}\right.$, Fort Atkinson, WI, USA) taken from the last drinker of the poultry house. The environmental samples consisted of boot swabs obtained by covering rubber boots with sterile cotton covers, which were collected after walked for $30 \mathrm{~min}$ in a zigzag pattern over the length of the chicken house [16,17]. The faecal samples were obtained from farm operators that previously have given their consent. Samples were transported under refrigeration conditions $\left(4^{\circ} \mathrm{C}\right)$ to the Laboratory of Veterinary Diagnosis, University of Tolima, Ibagué, Colombia, and processed within $12 \mathrm{~h}$ for Salmonella isolation.

All experimental procedures followed the guidelines from the Bioethics committee of the Central Research Office from University of Tolima based on the Law 84/1989 and Resolution 8430/1993 of Colombia government, and the Guide for the Care and Use of Agricultural Animals in Research and Teaching [18].

\subsection{Salmonella Isolation and Identification}

Microbiological isolation of Salmonella spp. followed specific standard procedures ISO/6579: 2002/AMD1: 2007, the Colombian Technical Standard (NTC) 4574, the standard issued by the authority Instituto Colombiano Agropecuario (ICA). Briefly, feed and water samples were pre-enriched 1:10 in buffer peptone water (BPW) (Oxoid, Basingstoke, Hampshire, UK); the cloacal swabs pool and boot swabs were mixed with $25 \mathrm{~mL}$ of BPW. All samples were incubated at $37^{\circ} \mathrm{C} \pm 1{ }^{\circ} \mathrm{C}$ for $24 \mathrm{~h}$. Then, $0.1 \mathrm{~mL}$ of pre-enrichment medium was inoculated into $10 \mathrm{~mL}$ of Rappaport Vassiliadis broth (Oxoid, Basingstoke, Hampshire, UK) and then it was incubated at $41.5^{\circ} \mathrm{C} \pm 1.0^{\circ} \mathrm{C}$ for $24 \mathrm{~h}$. A second aliquot $(0.1 \mathrm{~mL})$ of pre-enriched medium was inoculated into $10 \mathrm{~mL}$ Tetrathionate broth (Oxoid, Basingstoke, Hampshire, UK) and incubated at $37^{\circ} \mathrm{C} \pm 1{ }^{\circ} \mathrm{C}$ for $24 \mathrm{~h}$. The faecal samples from farm workers were directly inoculated in Rappaport Vassiliadis and Tetrathionate broth and incubated at $41.5^{\circ} \mathrm{C} \pm 1.0^{\circ} \mathrm{C}$ for $24 \mathrm{~h}$. Then, an aliquot of Rappaport Vassiliadis and Tetrathionate cultures were inoculated into Xylose Lysine Deoxycholate agar (XLD) (Merck, Darmstadt, Germany) and MacConkey agar (Oxoid, Basingstoke, Hampshire, UK) selective solid media and incubated at $37^{\circ} \mathrm{C} \pm 1{ }^{\circ} \mathrm{C}$ for $24-48 \mathrm{~h}$. Suspicious Salmonella colonies were confirmed by culture in Xylose Lysine Tergitol-4 (XLT4) agar (Merck, Darmstadt, Germany) at $35^{\circ} \mathrm{C} \pm 1{ }^{\circ} \mathrm{C}$ for $18-24 \mathrm{~h}$ and Rambach agar (Merck, Darmstadt, Germany) at $37^{\circ} \mathrm{C}$ for 24-48 h. Subsequently, the Salmonella colonies were tested for agglutination with Poly A-I and Vi antiserum (Difco ${ }^{\circledR}$ 222641; Becton Dickinson and Co, Sparks, MD, USA). Finally, the Salmonella isolates were biochemically characterized using the API-20E ${ }^{\circledR}$ (BioMérieux's, Marcy l'Etoile, France) enteric identification system. Farms were identified as positive for Salmonella when at least one sample was positive in the bacteriological culture. The Salmonella prevalence was calculated by dividing the number of farms classified as positive by the total number of sampled farms.

\subsection{Molecular Confirmation of Salmonella}

Salmonella isolates were confirmed by amplifying the inv $A$ gene, which is conserved in Salmonella serovars [19].

Genomic DNA (gDNA) was extracted from all Salmonella isolates using the Invisorb ${ }^{\circledR}$ Spin Universal Kit (Stratec, Berlin, Germany) and a fragment of the invA gene was amplified by using the forward (5'-GTGAAATTATCGCCACGTTCGGGCAA- $\left.3^{\prime}\right)$ and reverse 
$5^{\prime}$-(TCATCGCACCGTCAAAGGAACC-3') primers [20]. Endpoint PCR was carried out in a total volume of $25 \mu \mathrm{L}$, containing $1 \mu \mathrm{L}$ of gDNA template, $1 \mu \mathrm{L}$ of forward primer, $1 \mu \mathrm{L}$ of reverse primer, $1 \mu \mathrm{L}$ of Taq polymerase, $2.5 \mu \mathrm{L}$ of buffer $10 \mathrm{X}, 2 \mu \mathrm{L}$ of $\mathrm{MgCl}_{2}, 2.5 \mu \mathrm{L}$ dNTP and $14 \mu \mathrm{L}$ of nuclease free water. PCR was performed in a BIO-RAD T100 ${ }^{\mathrm{TM}}$ thermal cycler (Bio-Rad, Hercules, CA, USA) with the following conditions-denaturation of $3 \mathrm{~min}$ at $95^{\circ} \mathrm{C}, 35$ cycles of amplification with $30 \mathrm{~s}$ at $95^{\circ} \mathrm{C}$ (denaturation), $30 \mathrm{~s}$ at $55^{\circ} \mathrm{C}$ (annealing), and $90 \mathrm{~s}$ at $72{ }^{\circ} \mathrm{C}$ (extension), followed by $5 \mathrm{~min}$ at $72{ }^{\circ} \mathrm{C}$ for final extension and then resolved by electrophoresis on $2 \%$ agarose gel. The reaction products were stained with HydraGreen $^{\mathrm{TM}}$ (ACTGene, Piscataway, NJ, USA) and visualized under the UV light by using a trans-illumination system ENDURO ${ }^{\mathrm{TM}}$ GDS (Labnet International, Inc, Woodbridge, NJ, USA).

\subsection{Salmonella Serotyping}

All Salmonella isolates from broilers farms were serotyped following the WhiteKauffmann-Le Minor scheme for $\mathrm{O}$ and $\mathrm{H}$ antigens by using commercial antisera (Difco, Becton Dickinson and Co., Sparks, MD, USA). The serovars of Salmonella are based on the nomenclature described by the Judicial Commission of the International Committee on Systematics of Prokaryotes. The serotyping test was carried out at the National Laboratory of Veterinary Diagnosis of ICA (Bogotá, Colombia).

\subsection{Molecular Characterization by Pulse Field Gel Electrophoresis (PFGE)}

Salmonella isolates were analysed by PFGE using CHEF-DR III equipment (Bio-Rad, Hercules, CA, USA) at the National Reference PFGE Laboratory of Colombian National Health Institute (INS), following the PulseNet protocol [21,22]. Briefly, the gDNA from each Salmonella isolate was released into agarose plug gels and digested with the XbaI restriction enzyme (Promega, Madison, WI, USA). The DNA fragments were separated on a PFGE-certified $1 \%$ agarose gel (Bio-Rad, Hercules, CA, USA) with 0.5X Tris-borate-EDTA running buffer for $17 \mathrm{~h}$ at $6 \mathrm{~V} / \mathrm{cm}$ with increasing pulse times. The XbaI-digested Salmonella Braenderup H9812 DNA was used as a reference and size standard. The gels were stained with ethidium bromide and analysed using the Gel Compare II ${ }^{\circledR}$ software (Applied Maths, Sint-Martens-Latem, Belgium). The similarity was calculated by the Dice coefficient, and a dendrogram was constructed by cluster analysis using the unweighted pair group method with arithmetic mean (UPGMA). A band position tolerance of $1.5 \%$ was used for analysing the PFGE fingerprints.

\subsection{Multiplex PCR for the Discrimination of $d T+$ and $d T-$ Salmonella Isolates}

For the discrimination of $\mathrm{dT}+$ and dT - Salmonella isolates, a fragment of $290 \mathrm{bp}$ was amplified by using primers 166 (5'-GTAAGGGTAATGGGTTCC-3') and 167 (5'-CACATTAT TCGCTCAATGGAG-3') [23]. In addition, for the identification of the genus, primers ST11 (5'-AGCCAACCATTGCTAAATTGGCGCA-3') and ST15 (5'-GGTAGAAATTCCCAGCGG GTACTG-3' ${ }^{\prime}$ were used [24]. The PCR was carried out in a total volume of $25 \mu \mathrm{L}$, composed of $12.8 \mu \mathrm{L}$ of distilled-deionized water, $5 \mu \mathrm{L}$ of $5 \mathrm{X}$ green GoTaq ${ }^{\circledR}$ Flexi Buffer (Promega, Madison, WI, USA), $2 \mu \mathrm{L}$ of dNTPs (1.5 mM) (Invitrogen, Carlsbad, CA, USA), $1 \mu \mathrm{L}$ of each primer (166 and 167) $(10 \mathrm{pmol} / \mu \mathrm{L}), 0.5 \mu \mathrm{L}$ of each primer (ST11 and ST15) $(10 \mathrm{pmol} / \mu \mathrm{L})$, $1 \mu \mathrm{L} \mathrm{MgCl} 2(25 \mathrm{mM}), 0.125 \mu \mathrm{L}$ of GoTaq ${ }^{\circledR}$ Flexi DNA polymerase (Promega, Madison, WI, USA) and $1 \mu \mathrm{L}$ of the gDNA as template. The amplification was carried out in a ProFlex PCR System (Applied Biosystems, Carlsbad, CA, USA) with an initial denaturation step at $95{ }^{\circ} \mathrm{C}$ for $3 \mathrm{~min}$, followed by 35 cycles of denaturation at $95^{\circ} \mathrm{C}$ for $30 \mathrm{~s}$, annealing at $55^{\circ} \mathrm{C}$ for $30 \mathrm{~s}$, extension at $72{ }^{\circ} \mathrm{C}$ for $30 \mathrm{~s}$ and a last step of final extension at $72{ }^{\circ} \mathrm{C}$ for $5 \mathrm{~min}$. Amplicons were revealed on $1 \%$ agarose gel by electrophoresis (PowerPac ${ }^{\mathrm{TM}} \mathrm{HC}$, Bio-Rad, Bio-Rad, Hercules, CA, USA) using GeneRuler 100 bp DNA Ladder (Thermo Fisher Scientific, Waltham, MA, USA). The gel was stained with HydraGreen ${ }^{\mathrm{TM}}$ (ACTGene, Piscataway, NJ, USA) and visualized under the UV light, using the ENDURO ${ }^{\mathrm{TM}}$ GDS gel documentation system (Labnet International, Inc, Woodbridge, NJ, USA). 


\section{Results}

\subsection{Prevalence of Salmonella}

A total of 15 farms were sampled from which four farms were found positive to Salmonella spp., which represents a prevalence of $26.67 \%(4 / 15)$. From all samples analysed (135), $17.78 \%$ were positive for Salmonella isolation (24/135) and the microorganism was isolated most frequently from cloacal swab samples $(79.17 \%, n=19)$, followed by the boot swabs samples $(16.67 \%, n=4)$ and feed samples $(4.16 \%, n=1)$. The sampled house farm facilities only had two types of structure-bamboo or metal, they also had a floor in concrete or soil. However, approximately $75 \%$ of the positive farms were characterized by facilities constructed from a bamboo and soil floor, and only $25 \%$ of positive farms had metallic and concrete floor facilities. All faecal samples provided by farm operators were negative for the presence of Salmonella.

\subsection{Molecular Confirmation of Salmonella Genus by PCR}

All Salmonella isolates were confirmed by PCR amplification of a $284 \mathrm{bp}$ DNA fragment of the invasion gene invA (Figure 1).
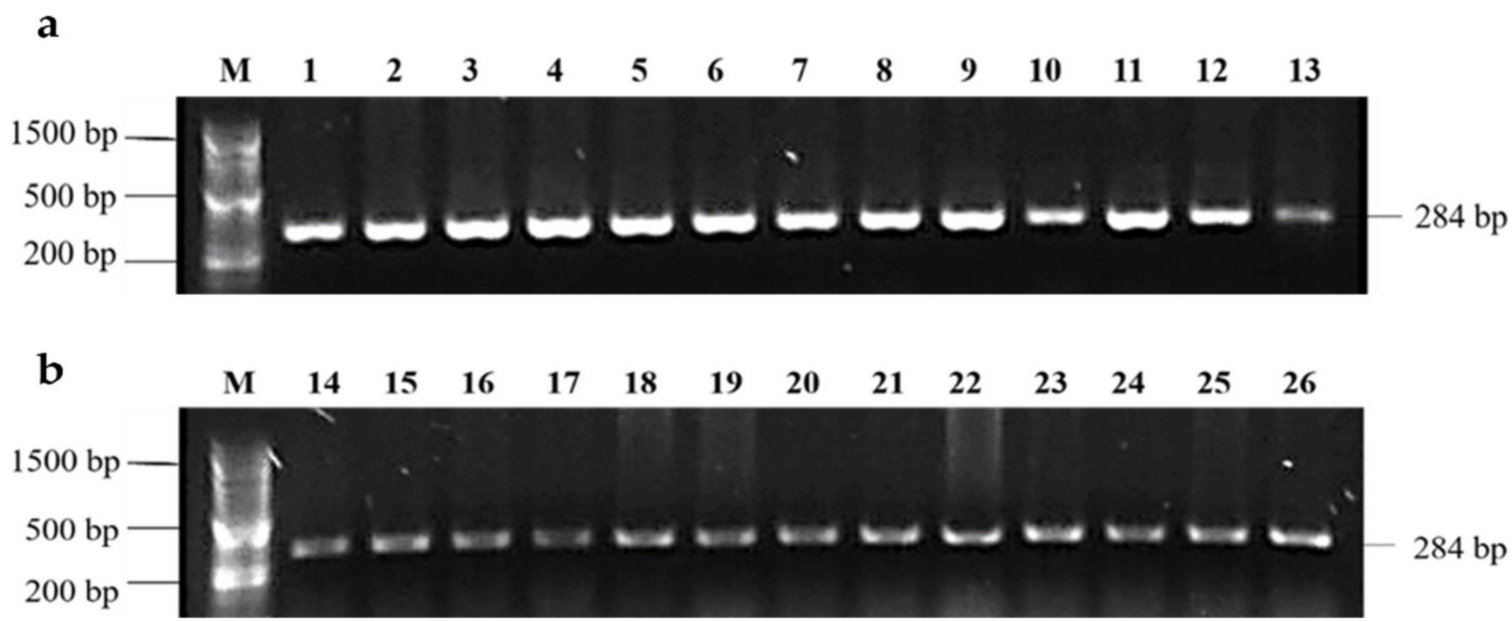

Figure 1. PCR amplification of $284 \mathrm{bp}$ DNA fragment from the invasion gene invA of Salmonella isolated from broilers farms in Tolima, Colombia. M-100 bp marker; (a) lanes 1-12 and (b) lanes 14-25-Salmonella isolates from Tolima broiler farms; lane 13 and 26-positive control Salmonella Enteritidis ATCC 13076.

\subsection{Salmonella Serovars}

The 24 Salmonella isolates were subjected to the White-Kauffmann-Le minor serotyping scheme and all isolates were identified as Salmonella Paratyphi B.

\subsection{PFGE Analysis}

Twenty-four Salmonella isolates were analysed by PFGE and showed three highly similar clusters (>89.9\%) and one significantly different Salmonella isolate (Figure 2). Cluster I was composed of seven isolates from cloacal swabs and environmental swabs. Although five isolates showed $100 \%$ Dice similarity index, there were two isolates (UT2-10, 11) slightly different (one additional band) from the previous ones (Dice index of $97.1 \%$ ). The cluster II was composed of six isolates obtained also from cloacal swabs and boot swabs and showed one Salmonella isolate slightly different (UT2-21) with a 99\% Dice similarity index. The cluster III (Dice index of $100 \%$ ) was composed of ten isolates that were obtained mostly from cloacal swabs but also from boots swabs and feed samples. Clusters I and II showed $92 \%$ Dice similarity index, and together showed $89.9 \%$ Dice similarity index with Cluster III. Finally, the isolate UT2-1 formed an independent pattern and showed only $10.2 \%$ Dice similarity index with previous clusters. 


\subsection{Molecular Discrimination of $d T+$ and $d T-$ Salmonella Isolates}

All Salmonella Paratyphi B $(n=24)$ isolates were d-tartrate-fermenting isolates $(\mathrm{dT}+)$ confirmed by amplification of a $290 \mathrm{bp}$ fragment from the putative cation transporter STM 3356 gene (Figure 3 ).

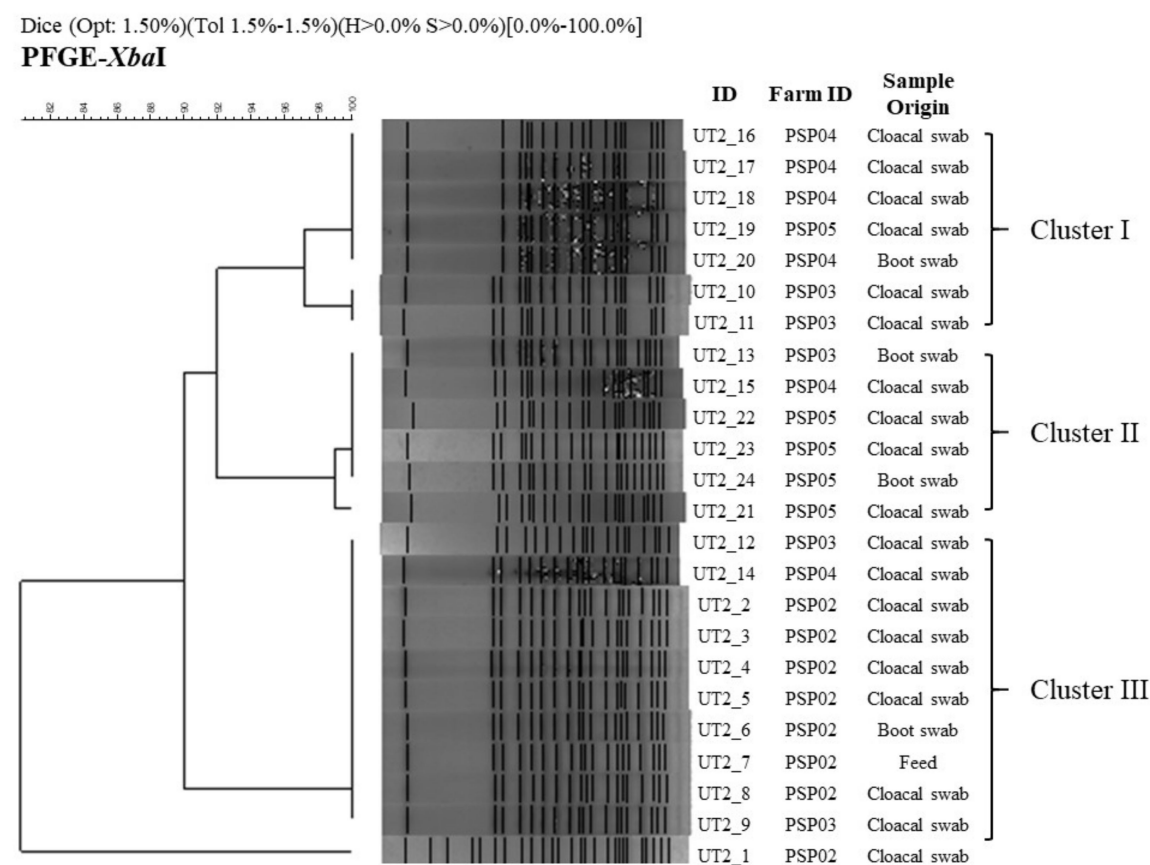

Figure 2. Macrorestriction patterns of 24 Salmonella Paratyphi B generated by pulsed-field gel electrophoresis (PFGE) of XbaI-digested genomic DNA. A similarity analysis was performed using the Dice coefficient, and the dendrogram was generated by the unweighted pair group method with arithmetic averages using the Gel Compare II software (Applied Maths, Sint-Martens-Latem, Belgium). Lanes UT2_1 to UT2_24 correspond to the genomic DNA fingerprinting from each Salmonella isolate from the broiler farms in the Tolima region collected from year 2015 to 2016.

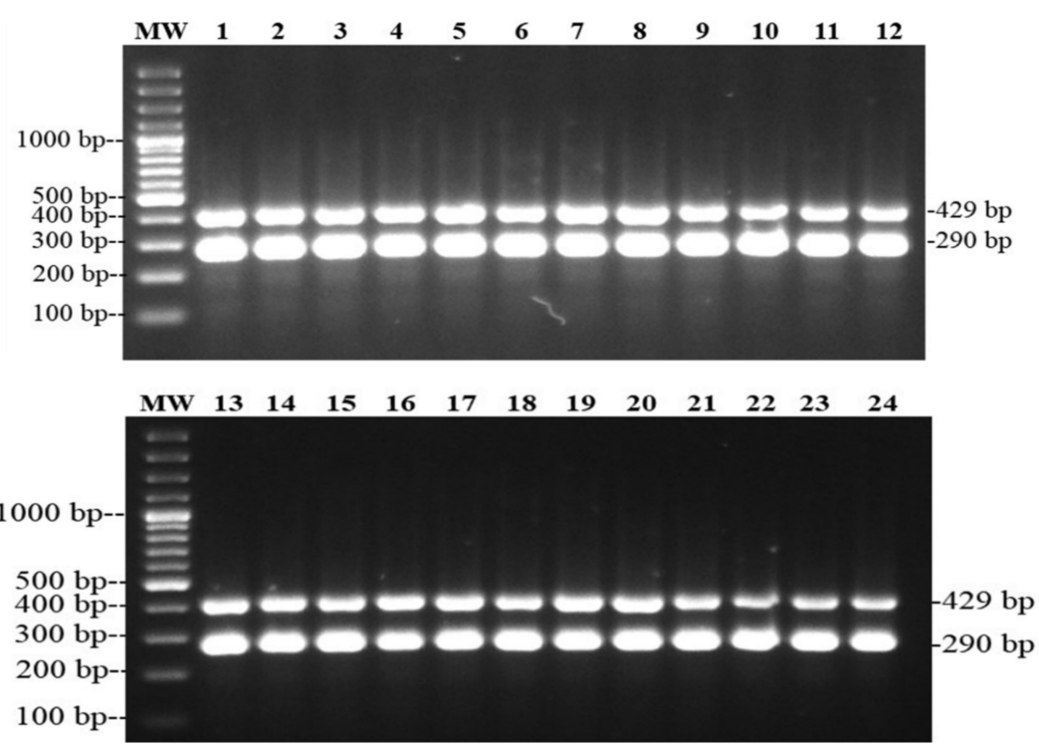

Figure 3. PCR amplification of $290 \mathrm{bp}$ of the putative cation transporter STM3356 gene identifying dT+ Salmonella isolated from broilers farms in Tolima, Colombia. MW-GeneRuler 100 bp Plus DNA Ladder ((Thermo Fisher Scientific, Waltham, MA, USA); lanes 1-24: Salmonella Paratyphi B isolates from Tolima broiler farms. The $429 \mathrm{bp}$ band corresponds to the genus specific Salmonella control. 


\section{Discussion}

This study for the first time estimated a $26.67 \%$ prevalence of Salmonella in broiler farms sampled in Tolima region, Colombia. This result is significantly lower than the $41 \%$ prevalence previously reported in broiler farms from Santander and Cundinamarca regions in 2012 [14] and 40.5\% median prevalence of Salmonella in broiler production estimated worldwide [25]. Since the prevalence of Salmonella in broiler carcasses marketed in Ibague city was $17.4 \%$ in 2014 and S. Paratyphi B was the serotype most frequently (36.17\%) [26] isolated, together the data suggest the dissemination of S. Paratyphi B from poultry farm to consumer. Salmonella Paratyphi B variant java has been described as a reservoir of complex antimicrobial resistance profiles and diverse mobile genetic elements in poultry production in Colombia, and this variant was traced from farm to retails stores, but Salmonella Paratyphi B ST28 could have an amplified action range in human hosts in Latin America $[27,28]$. In addition, positive farms exhibit a common rudimentary production facility constructed from bamboo, which represents a possible additional risk because of its limited disinfection options and it could not represent an optimal physical barrier to avoid entrance of another natural reservoir [12]. These results show that the presence of Salmonella in poultry production could be dynamic in time and space [29,30], and health authorities must promote continued strengthening of integrated surveillance and guarantee Salmonella to be part of the local and national foodborne agenda, as a priority in public health. Salmonella has more than 2600 serovars, based on $46 \mathrm{O}$ antigens and $114 \mathrm{H}$ antigens [31] which may differ in their ability to colonise the host and persist in the environment. In our study, all isolates belonged to Salmonella Paratyphi B serovar which is recognized to have two variants, fermenting tartrate $(\mathrm{dT}+)$ and non-fermenting tartrate (dT-) [32]. These two variants have very different pathogenic characteristics$S$. Paratyphi B (dT-) variant could produce invasive infections and paratyphoid fever with life threatening infection in humans [33]. However, in this study, S. Paratyphi B isolates were found to be tartrate $(\mathrm{dT}+)$ fermenting variants that are associated with acute diarrheic disease (self-controlling) [33,34]. S. Paratyphi B (dT+) has animal reservoirs that could be the source of infection [35]. On the other hand, this variant was the most prevalent in broiler flocks in Belgium (12.3\%) and Germany (10.8\%) [36]. However, the result of this study contrasts with the work done by Rodriguez et al. [26], where at least 14 different serovars were isolated from broiler carcasses $(47 / 270)$ marketed in the capital of Tolima region. As has been discussed in previous works, the results strengthen the hypothesis that contamination of broiler carcasses with a number of potentially pathogenic serovars of Salmonella might be occurring. Some authors have reported Salmonella carcase contamination during handling and processing in abattoirs, transport and exhibition at the market place, and suggest poor hygienic and disinfection practices at those processes and steps of the poultry chain [37-39]. In our study, Salmonella Paratyphi B was isolated from one feed sample $(0.74 \%)$, andalthough this frequency is very low, it raised concerns regarding the quality of the feed, since this may constitute an efficient mechanism of widespread contamination of poultry flocks with Salmonella. In line, other serovars such as Salmonella Shannon were also isolated from feed samples $(28.57 \%)$ obtained in laying hen farms in this region of Colombia [12]. On the other hand, $96 \%(19 / 24)$ of $S$. Paratyphi $B$ recovered was isolated from cloacal and environmental samples. These results could represent diverse contamination sources ranging from possible contaminated parental flocks or the hatchery machines and then contamination of flock to flock populations, to environmental contamination factors as poor bio-security practices, residual contamination (dust), inefficient flaming process, litter recycling, other biological reservoirs (pets or pests), depopulation time and sanitation [40-42].

Previous studies have reported that $S$. Paratyphi B isolated from poultry products in Colombia [14,43] have remarkable antibiotic resistance, and 22/24 Salmonella Paratyphi $\mathrm{B}$ isolates in this study were resistant to three antibiotic classes, penicillins (ampicillin), aminoglycosides (streptomycin), and cephalosporins (ceftriaxone and ceftazidime), that may have an impact in the treatments of human infections [44]. Furthermore, antimicrobial 
resistance constitutes a global trend and international food trading restrictions could be pressuring drivers to promote control of Salmonella in Colombia $[33,45,46]$. In the Netherlands and Germany, this variant was reported in isolates from poultry which showed multidrug-resistance (MDR), causing the disease in humans [32,47].

All isolates were grouped into three closely related PFGE clusters but one isolate had a very different PFGE pattern. These results indicate a possible common source of contamination with Salmonella between different farms, presumably water, contaminated feed, parent flocks or cross-contamination with environmental sources [28,31], based on the wide distribution of those clusters identified in broiler farms and high genetic relation $(\mathrm{SI}=0.899)$ between them [48,49], and additional local studies suggesting high heterogeneity in reported PFGE patterns in a specific geographical distribution [14,48]. The results suggest an association between the homogeneity in PFGE patterns obtained in this study with a common contaminating source. However, contamination of broiler production systems with a single genetic related serovar could mean a unified plan of hygiene and disinfection control actions for all positive production systems sampled in the Tolima region, which is improbable.

\section{Conclusions}

Salmonella Paratyphi B was found as the predominant serovar present in broiler farms sampled in the Tolima region. Molecular characterization (PFGE) identified that those Salmonella Paratyphi B isolates presented high genetic relatedness, indicating a possible common contamination source across different farms. Despite this, $S$. Paratyphi $\mathrm{B} \mathrm{dT}+$ is not related to acute human illness in Colombia, however, being a successful reservoir of antimicrobial resistance, it is important for public health. Additional studies are needed to clarify the main source of Salmonella observed in the Tolima poultry industry, since $S$. Paratyphi B is a common serovar isolated not only from broiler farms, but also from marketed chicken carcasses, and eggs commercialized in the Tolima region, and it could represent a starting point. This study highlights the need to establish local or national monitoring programs to generate longitudinal data of pathogen dynamics in animal production in Colombia. By integrating animal data to food and clinical data, it would be possible to generate bio-contention plans and actions to early identify emerging pathogens of interest in animal and human health.

Author Contributions: Conceptualization, R.R.-H., N.V.G.; methodology, R.R.-H., N.V.G., J.F.B. and L.C.F.; software, R.R.-H. and J.F.B.; validation, R.R.-H., N.V.G., J.F.B., L.C.F., J.F.C., M.P.H.-S. and I.R.-B.; formal analysis, R.R.-H., N.V.G., J.F.B.; investigation, R.R.-H., N.V.G., L.C.F., J.F.B.; resources, J.F.C. and M.P.H.-S.; data curation, N.V.G., R.R.-H. and J.F.B.; writing-original draft preparation, R.R.-H., N.V.G., J.F.B. and I.R.-B.; writing-review and editing, R.R.-H., N.V.G., J.F.B., M.P.H.-S., I.R.-B.; supervision, R.R.-H., N.V.G.; project administration, N.V.G.; funding acquisition, R.R.-H. All authors have read and agreed to the published version of the manuscript.

Funding: This research was funded by Research Office of the University of Tolima project 130214 and Asociación de Médicos Veterinarios Especialistas en Avicultura-AMEVEA.

Institutional Review Board Statement: This study was approved for Research and Technologic development office at the University of Tolima project 130214 and AMEVEA 2014 call for the Research Support Fund.

Informed Consent Statement: The human samples collection was voluntarily obtained through informed consent from all subjects involved in this study, based on Resolution number 8430 - 1993 from the Colombian Healthcare department.

Data Availability Statement: Not applicable.

Acknowledgments: A special thanks to the Tolima poultry producers, who have allowed sampling in their farms, and identifying problems to improve the processes within the companies and productions, to provide a better poultry product. 
Conflicts of Interest: The authors declare no conflict of interest, and the funders had no role in the design of the study; in the collection, analyses, or interpretation of data; in the writing of the manuscript, or in the decision to publish the results.

\section{References}

1. World Health Organization. Salmonella (Non-Typhoidal). Available online: https://www.who.int/es/news-room/fact-sheets/ detail/salmonella-(non-typhoidal) (accessed on 20 December 2020).

2. Antunes, P.; Mourão, J.; Campos, J.; Peixe, L. Salmonellosis: The role of poultry meat. Clin. Microbiol. Infect. 2016, $22,110-121$. [CrossRef]

3. Centers for Disease Control and Prevention Salmonella Page. Available online: https://www.cdc.gov/salmonella/index.html\#: $\sim\{\}:$ text=CDCestimatesSalmonellabacteriacause,\%2Cfever\%2Candstomachcramps (accessed on 1 December 2020).

4. European Food Safety Authority. EFSA Explains Zoonotic Diseases: Food-Borne Zoonotic Diseases. Available online: https: //www.efsa.europa.eu/sites/default/files/corporate_publications/files/factsheetfoodbornezoonoses2014_en.pdf (accessed on 18 December 2020).

5. Rajan, K.; Shi, Z.; Ricke, S.C. Current aspects of Salmonella contamination in the US poultry production chain and the potential application of risk strategies in understanding emerging hazards. Crit. Rev. Microbiol. 2017, 43, 370-392. [CrossRef] [PubMed]

6. Braden, C.R. Salmonella enterica serotype enteritidis and eggs: A national epidemic in the United States. Clin. Infect. Dis. 2006, 43, 512-517. [CrossRef]

7. Fandiño, L.C.; Verjan, N. A Common Salmonella enteritidis sequence type from poultry and human gastroenteritis in Ibagué, Colombia. Biomédica 2019, 39. [CrossRef] [PubMed]

8. European Food Safety Authority Salmonella. Available online: https://www.efsa.europa.eu/es/press/news/120308 (accessed on 1 December 2020).

9. Instituto Nacional de Salud. Salmonella spp: “Colombia 1997-2018"; Dirección Redes En Salud Pública, Instituto Nacional de Salud: Bogotá, Colombia, 2019; pp. 1-25.

10. Le Bouquin, S.; Allain, V.; Rouxel, S.; Petetin, I.; Picherot, M.; Michel, V.; Chemaly, M. Prevalence and risk factors for Salmonella spp. Contamination in French broiler-chicken flocks at the end of the rearing period. Prev. Vet. Med. 2010, 97, 245-251. [CrossRef]

11. Namata, H.; Méroc, E.; Aerts, M.; Faes, C.; Abrahantes, J.C.; Imberechts, H.; Mintiens, K. Salmonella in Belgian Laying Hens: An identification of risk factors. Prev. Vet. Med. 2008, 83, 323-336. [CrossRef] [PubMed]

12. Rodríguez, R.; Fandiño, C.; Donado, P.; Guzmán, L.; Verjan, N. Characterization of Salmonella from commercial egg-laying hen farms in a central region of Colombia. Avian Dis. 2015, 59, 57-63. [CrossRef] [PubMed]

13. Mogollon, C.; Rodriguez, V.; Verjan, N. Serotyping and molecular typing of salmonella isolated from commercial eggs at Ibague, Colombia. Rev. Salud Anim. 2016, 38, 1-10.

14. Donado-Godoy, P.; Gardner, I.; Byrne, B.A.; Leon, M.; Perez-Gutierrez, E.; Ovalle, M.V.; Tafur, M.A.; Miller, W. Prevalence, risk factors, and antimicrobial resistance profiles of Salmonella from commercial broiler farms in two important poultry-producing regions of Colombia. J. Food Prot. 2012, 75, 874-883. [CrossRef]

15. Castro-Var, R.; de Rubio, L.C.F.; Vega, A.; Rondon-Bar, I. Phenotypic and genotypic resistance of salmonella heidelberg isolated from one of the largest poultry production region from Colombia. Int. J. Poult. Sci. 2019, 18, 610-617. [CrossRef]

16. Carrique-Mas, J.J.; Davies, R.H. Sampling and bacteriological detection of Salmonella in poultry and poultry premises: A review. Rev. Sci. Tech. 2008, 27, 665. [CrossRef]

17. European Commission Baseline Study on the Prevalence of Salmonella in Broiler Flocks of Gallus Gallus in the EU: Technical Specifications. Available online: http://ec.europa.eu/food/food/biosafety/salmonella/tech_spec_sanco-1688-2005_rev1_en.pdf (accessed on 18 December 2020).

18. FASS (Federation of Animal Science Societies) Writing Committee. Guide for the Care and Use Ofagricultural Animals in Research and Teaching, 3rd ed.; Federation of Animal Science Societies: Champaign, IL, USA, 2010; ISBN 9781884706110.

19. Li, Q.; Cheng, W.; Zhang, D.; Yu, T.; Yin, Y.; Ju, H.; Ding, S. Rapid and sensitive strategy for salmonella detection using an inva gene-based electrochemical DNA sensor. Int. J. Electrochem. Sci. 2012, 7, 844-856.

20. Rahn, K.; De Grandis, S.A.; Clarke, R.C.; McEwen, S.A.; Galán, J.E.; Ginocchio, C.; Curtiss, R.; Gyles, C.L. Amplification of an InvA gene sequence of Salmonella typhimurium by polymerase chain reaction as a specific method of detection of Salmonella. Mol. Cell. Probes 1992, 6, 271-279. [CrossRef]

21. CDC. Standard Operating Procedure for Pulsenet PFGE of Escherichia coli O157: H7, Escherichia coli Non-O157 (STEC), Salmonella Serotypes, Shigella sonnei and Shigella flexneri. CDC 2013, 157, 1-13. Available online: https:/ / www.cdc.gov/pulsenet/pdf/ecolishigella-salmonella-pfge-protocol-508c.pdf (accessed on 10 December 2020).

22. Ribot, E.M.; Fair, M.A.; Gautom, R.; Cameron, D.N.; Hunter, S.B.; Swaminathan, B.; Barrett, T.J. Standardization of pulsed-field gel electrophoresis protocols for the subtyping of Escherichia Coli O157:H7, Salmonella, and Shigella for PulseNet. Foodborne Pathog. Dis. 2006, 3, 59-67. [CrossRef]

23. Malorny, B.; Bunge, C.; Helmuth, R. Discrimination of D-Tartrate-Fermenting and -Nonfermenting Salmonella enterica Subsp. enterica isolates by genotypic and phenotypic methods. J. Clin. Microbiol. 2003, 41, 4292-4297. [CrossRef]

24. Aabo, S.; Rasmussen, O.F.; Rossen, L.; Sørensen, P.D.; Olsen, J.E. Salmonella Identification by the polymerase chain reaction. Mol. Cell. Probes 1993, 7, 171-178. [CrossRef] [PubMed] 
25. Castro-vargas, R.E.; Herrera-sánchez, M.P.; Rodríguez-hernández, R. Antibiotic resistance in Salmonella spp. Isolated from Poultry: A global overview. Vet. World 2020, 13, 2070-2084. [CrossRef] [PubMed]

26. Rodriguez, J.; Rondón, I.; Verjan, N. Serotypes of Salmonella in Broiler Carcasses Marketed at Ibague, Colombia. Rev. Bras. Ciência Avícola 2015, 17, 545-552. [CrossRef]

27. Castellanos, L.R.; van der Graaf-van Bloois, L.; Donado-Godoy, P.; León, M.; Clavijo, V.; Arévalo, A.; Bernal, J.F.; Mevius, D.J.; Wagenaar, J.A.; Zomer, A.; et al. Genomic characterization of extended-spectrum cephalosporin-resistant Salmonella enterica in the Colombian Poultry Chain. Front. Microbiol. 2018, 9, 2431. [CrossRef]

28. Donado-Godoy, P.; Castellanos, R.; León, M.; Arevalo, A.; Clavijo, V.; Bernal, J.; León, D.; Tafur, M.A.; Byrne, B.A.; Smith, W.A.; et al. The establishment of the colombian integrated program for antimicrobial resistance surveillance (COIPARS): A pilot project on poultry farms, slaughterhouses and retail market. Zoonoses Public Health 2015, 62, 58-69. [CrossRef]

29. Foley, S.L.; Nayak, R.; Hanning, I.B.; Johnson, T.J.; Han, J.; Ricke, S.C. Population dynamics of Salmonella enterica serotypes in commercial egg and poultry production. Appl. Environ. Microbiol. 2011, 77, 4273-4279. [CrossRef]

30. Kloska, F.; Beyerbach, M.; Klein, G. Infection dynamics and antimicrobial resistance profile of Salmonella paratyphi B D-Tartrate Positive (Java) in a persistently infected broiler barn. Int. J. Environ. Res. Public Health 2017, 14, 101. [CrossRef]

31. Issenhuth-Jeanjean, S.; Roggentin, P.; Mikoleit, M.; Guibourdenche, M.; de Pinna, E.; Nair, S.; Weill, F.X. Supplement 2008 e 2010 (No. 48) to the White e Kauffmann e Le Minor. Res. Microbiol. 2014, 165, 526-530. [CrossRef] [PubMed]

32. Miko, A.; Guerra, B.; Schroeter, A.; Dorn, C.; Helmuth, R. Molecular characterization of multiresistant D-tartrate-positive Salmonella enterica serovar paratyphi B isolates. J. Clin. Microbiol. 2002, 40, 3184-3191. [CrossRef]

33. Gand, M.; Mattheus, W.; Saltykova, A.; Roosens, N.; Dierick, K.; Marchal, K.; De Keersmaecker, S.C.J.; Bertrand, S. Development of a real-time PCR method for the genoserotyping of Salmonella paratyphi B variant java. Appl. Microbiol. Biotechnol. 2019, 103, 4987-4996. [CrossRef] [PubMed]

34. Connor, T.R.; Owen, S.V.; Langridge, G.; Connell, S.; Nair, S.; Reuter, S.; Dallman, T.J.; Corander, J.; Tabing, K.C.; Le Hello, S.; et al. What's in a Name? Species-wide whole-genome sequencing resolves invasive and noninvasive lineages of Salmonella enterica serotype paratyphi B. MBio 2016, 7. [CrossRef] [PubMed]

35. Ahmad, N.; Tang, S.; Hoon Bsc, G.; Kamel, M.; Ghani, A.; Yin, K.; Dipmlt, T. The discrimination of D-tartrate positive and d-tartrate negative S. enterica Subsp. enterica Serovar Paratyphi B isolated in Malaysia by Phenotypic and Genotypic Methods. Malays J. Pathol. 2012, 34, 35-39.

36. Huehn, S.; Helmuth, R.; Bunge, C.; Guerra, B.; Junker, E.; Davies, R.H.; Wattiau, P.; Van Pelt, W.; Malorny, B. Characterization of pathogenic and resistant genome repertoire reveals two clonal lines in Salmonella enterica Subsp. Enterica Serovar Paratyphi B (+)-tartrate positive. Foodborne Pathog. Dis. 2009, 6, 431-443. [CrossRef]

37. Althaus, D.; Zweifel, C.; Stephan, R. Analysis of a poultry slaughter process: Influence of Process stages on the microbiological contamination of broiler carcasses. Ital. J. Food Saf. 2017, 6, 7097. [CrossRef]

38. Cota, J.B.; da Silva, V.F.; Chambel, L.; Veloso, M.G.; Vieira-Pinto, M.; Oliveira, M. Pheno and genotyping of salmonella from slaughtered pigs in a portuguese abattoir reveal differential persistence ability. Vet. Microbiol. 2019, 239, 108457. [CrossRef]

39. Rivera-Pérez, W.; Barquero-Calvo, E.; Zamora-Sanabria, R. Salmonella Contamination risk points in broiler carcasses during slaughter line processing. J. Food Prot. 2014, 77, 2031-2034. [CrossRef]

40. Armwood, B.T.; Rieth, A.; Baldwin, L.; Roney, C.S.; Barbieri, N.L.; Logue, C.M. Assessing the Ability of maternal antibodies to protect broiler chicks against colonization by Salmonella heidelberg. Avian Dis. 2019, 63, 289-293. [CrossRef]

41. McWhorter, A.R.; Chousalkar, K.K. From hatch to egg grading: Monitoring of Salmonella Shedding in free-range egg production systems. Vet. Res. 2019, 50, 58. [CrossRef]

42. Voss-Rech, D.; Kramer, B.; Silva, V.S.; Rebelatto, R.; Abreu, P.G.; Coldebella, A.; Vaz, C.S.L. Longitudinal study reveals persistent environmental Salmonella heidelberg in Brazilian broiler farms. Vet. Microbiol. 2019, 233, 118-123. [CrossRef]

43. Donado-Godoy, P.; Clavijo, V.; León, M.; Tafur, M.A.; Gonzales, S.; Hume, M.; Alali, W.; Walls, I.; Lo Fo Wong, D.M.; Doyle, M.P. Prevalence of Salmonella on retail broiler chicken meat carcasses in Colombia. J. Food Prot. 2012, 75, 1134-1138. [CrossRef] [PubMed]

44. Herrera-Sánchez, M.P.; Rodríguez-Hernández, R.; Rondón-Barragán, I.S. Molecular characterization of antimicrobial resistance and enterobacterial repetitive intergenic consensus-PCR as a molecular typing tool for Salmonella spp. Isolated from poultry and humans. Veter World 2020, 13, 1771-1779. [CrossRef] [PubMed]

45. Perin, A.P.; Martins, B.T.F.; Barreiros, M.A.B.; Yamatogi, R.S.; Nero, L.A.; Dos Santos Bersot, L. Occurrence, quantification, pulse types, and antimicrobial susceptibility of Salmonella sp. Isolated from chicken meat in the state of Paraná, Brazil. Braz. J. Microbiol. 2020, 51, 335-345. [CrossRef] [PubMed]

46. Quesada, A.; Reginatto, G.A.; Ruiz Español, A.; Colantonio, L.D.; Burrone, M.S. Antimicrobial resistance of Salmonella spp isolated animal food for human consumption. Rev. Peru. Med. Exp. Salud Publica 2016, 33, 32-44. [CrossRef] [PubMed]

47. van Pelt, W.; van der Zee, H.; Wannet, W.J.B.; van de Giessen, A.W.; Mevius, D.J.; Bolder, N.M. Explosive Increase of Salmonella Java in poultry in the Netherlands: Consequences for public health. Eurosurveillance 2003, 8, 31-35. [CrossRef] 
48. Donado-Godoy, P.; Byrne, B.A.; Hume, M.; León, M.; Pérez-Gutiérrez, E.; Vives Flores, M.J.; Clavijo, V.; Holguin, Á.; RomeroZuñiga, J.J.; Castellanos, R.; et al. Molecular characterization of Salmonella paratyphi B DT+ and Salmonella Heidelberg from poultry and retail chicken meat in Colombia by pulsed-field gel electrophoresis. J. Food Prot. 2015, 78, 802-807. [CrossRef] [PubMed]

49. Phongaran, D.; Khang-Air, S.; Angkititrakul, S. Molecular epidemiology and antimicrobial resistance of Salmonella isolates from Broilers and Pigs in Thailand. Vet. World 2019, 12, 1311-1318. [CrossRef] [PubMed] 